\title{
ATOTE \\ Kenya Primary School Teachers' Preparation in ICT Teaching: Teacher Beliefs, Attitudes, Self-Efficacy, Computer Competence, ANd Age
}

\author{
Gladwell Wambiri \\ Kenyatta University, Kenya \\ Mary N. Ndani \\ Kenyatta University, Kenya
}

\begin{abstract}
Information and Communication Technologies (ICT) has become globally recognized as an effective medium for learning. The Kenyan government made a commitment to provide computers for use in teaching in primary schools. This is expected to enable teachers to integrate ICT in their teaching beginning in primary standard one. Teachers will directly implement the ICT project at the classroom level, so are very crucial players to its effectiveness. This article discusses the preparedness of lower primary school teachers for this implementation process regarding their beliefs and attitudes, computer competence, and computer self-efficacy. The authors argue that the provision of computers and other infrastructure in schools may not automatically lead to integration of ICT in schools unless the government addresses teachers' beliefs and attitudes, computer competence and their self-efficacy. The authors recommend revision of the primary teacher education preparation syllabus and training practice for preservice teachers in ICT pedagogy to enhance their preparation to integrate ICT in their teaching in primary school.

Keywords: ICT Teacher Age, ICT Primary Education, Teacher Self-efficacy, Kenya Teacher Computer Competence, Kasarani Division, Kenya.
\end{abstract}

\section{Introduction}

The twenty-first century witnessed rapid globalization and infiltration of Information and Communication Technologies (ICT) in almost all sectors of life. The rapid advancement of ICT and the subsequent emergence of the "knowledge-based" society make it almost mandatory to integrate ICT in teaching and learning at all levels of schooling. The use of ICT in schools has many benefits to the learner. These include easy access to digital information and understanding of concepts (Brush, Glazewski and Hew, 2008); and facilitating student-centered and self- 
directed learning where students can select, organize, and interpret information and data (Catro Sanchez and Aleman, 2011). In addition, ICT improves teaching and learning quality (Shan FU (2013) and improves learning outcomes and learners' competencies (Andoh, 2012). ICT is therefore very crucial for teaching and learning today.

As such, educational systems and institutions need to incorporate teaching using ICT to prepare learners for life in the modern world and beyond. In this regard, Ogutu (2008) observed that to achieve the Kenya government vision of facilitating ICT as a universal tool for education and training, every educational institution, teacher, and learner should be equipped with appropriate ICT knowledge and skills and the relevant infrastructure provided.

The Kenya government in its "Vision 2030" envisages making the country a middle level economy by using ICT, and therefore committed itself to providing computers to children in primary schools (Kenya Government, 2007). The government expects teachers to integrate ICT in teaching from as early as primary standard one. It undertook an extensive electrification program to ensure consistent power supplies to previously unreached areas. However, availability of infrastructure does not automatically ensure integration of ICT in schools.

Effective implementation of ICT involves interplay of multiple factors besides provision of computers and infrastructure (Aktaruzzaman, Shamim and Clement, 2011). One vital group of factors significant in the integration of ICT in the classroom is the teacher factors. Teachers are significant players in the process of integrating ICT as they are directly involved in the implementation process (Bikos \& Tzifopoulos, 2011). As leaders in the planning and execution of the lesson, their personal characteristics including their beliefs and attitudes towards the use of technology, their level of training in ICT, and their self-efficacy in using ICT may influence its integration in teaching and learning.

\section{Teacher Beliefs and Attitudes towards ICT Use}

Studies show that teacher attitudes and beliefs are crucial in influencing their acceptance of and subsequent successful integration of ICT in the teaching/learning process (Huang \& Liaw, 2005; Hew \& Brush, 2007 and Keengwe \& Onchari, 2008). Further, Woodrow (1992) argues users need to have positive attitudes towards the innovation to successfully transform the educational practice. Teachers' attitudes are likely to be influenced by their perceptions on the usefulness of ICT. In this regard, Mingaine (2013) argues that teachers are more likely to use ICT if they perceive it to satisfy their own needs or those of their learners. Consistently, studies show that teachers' attitudes towards ICT largely influence their willingness to adopt and integrate ICT in their teaching. As Andoh (2012) found that Ghanaian teachers who perceived ICT to offer them opportunities for obtaining educational resources from the internet, improve teaching and learning process, and enhance students' participation and feedback to teachers, were more willing and ready to use ICT in teaching.

However, contrary findings, such as Eugene (2006) investigated the effect of teacher beliefs and attitudes towards use of ICT in schools found inconsistencies between practice in use of ICT in teaching and teacher beliefs and attitudes. The study attributed the apparent inconsistencies to various factors including lack of ICT resources and lack of access to appropriate technology, inadequate support from the management, and lack of necessary pedagogical training. This 
implied that even if teachers have positive attitudes, they must be effectively trained and have the relevant support.

Although the Kenya government is committed to the process of integrating ICT in primary schools and has integrated ICT in primary teacher education syllabus; teacher beliefs and attitudes towards use of ICT in schools remains unknown. There is need to assess teacher beliefs and attitudes towards ICT use as a measure to ensure successful implementation of Kenya's ICT program.

\section{ICT Training}

Another key factor in teachers' preparedness is their competence in using ICT in teaching and learning. Readiness to integrate ICT in teaching calls for teachers' ability to handle computers and other ICT gadgets and associated software. In this regard, Drent \& Meelisen (2008) established that the quality and level of teacher training influences effective adoption and use of ICT in schools. In another study, Simonson (2008) found that teachers' skills are related to their use of ICT in the teaching-learning process. Further, Bordbar (2010) reported that teachers' competence in computer use is a good predictor of ICT integration in teaching.

Research shows that training must be relevant if teachers are to be well equipped to use ICT. Most of the studies on ICT training for teachers were conducted with secondary school teachers. A study by Andoh (2012) reported that teacher training institutions emphasized training about technology as opposed to how teachers could use technology to teach. These findings echoed Muriithi (2005) who reported that ICT training in Kenya was limited to ICT literacy. Similarly, Mingaine (2013) reported that secondary school teachers did not have sufficient skills on how to integrate ICT in teaching and learning. Other studies in Kenya (Ayere, Odera \& Agak, 2010) reported that $55 \%$ of teachers in secondary schools did not have any ICT training at all. Of those who had training in ICT, $51 \%$ obtained training through personal initiatives after employment as teachers. Consequently, teachers in secondary schools in the Rift Valley region (Ng'eno, Githua and Changeiywo, 2013) were found to perceive themselves as ill-prepared to integrate ICT in mathematic instructions. The lack of ICT training could be due to a lack of serious focus on ICT in the teacher training program.

These secondary school findings cannot however be directly applied to primary school teachers because their training and expectations are different. ICT was integrated in the Kenya Primary Teacher Education (PTE) syllabus in 2008, so that by the time teachers are posted too teach, they are expected to have ICT knowledge. Still there remains the need to find out the extent of primary school teachers' perceived ability to teach using ICT based on their training. As such, this study was conducted to establish lower primary school teachers' readiness to implement ICT in primary school teaching and learning.

\section{Self-efficacy}

Self-efficacy in this study refers to the teacher's belief in his or her ability to perform an activity using computers. The focus is not on the skills one has, but on the teacher's judgment on what he or she can do with the skills one possesses. Available literature affirms that lack of self-efficacy in the use of computers could lead to lack of confidence in using ICT in the classroom. As Koliadis (1997) asserted that a person's self-efficacy can validly predict the behavior that the 
individual will demonstrate in performing a task. Further and consistent with that assertion Knezek \& Christenson (2006) argue that computer self-efficacy is related to confidence in computer technology; and Teo (2009) found teachers' self-efficacy to significantly predict intention to use and actual use of technology. His findings confirmed Compeau and Higgins (1995) finding that teachers with higher self-efficacy used computers more often and experienced less computer related anxiety. Other researchers also found a positive correlation between self-efficacy and computer use. Benson (2004), for example, found computer efficacy to correlate with the integration and development of modern technologies in educational practice. Self-efficacy may also be related to other teacher characteristics. Self-efficacy is therefore crucial in understanding teacher characteristics and their relation to teachers' effective use of ICT in the classroom. Integration of ICT in primary education being a relatively new development in Kenya, studies have not yet established teachers' self-efficacy in the use of computers.

\section{Teacher Age and Use of Computers}

A key factor in readiness for computer use and integration in teaching is teacher age. The level of self-efficacy is not equally distributed across ages. Gill and Dalgarno's (2008) study on influences of pre-service teacher preparedness to use ICT in the classroom found younger respondents to have higher confidence in their ability to teach using computers than older respondents. In Gill and Dalgarno's study, most mature students expressed reluctance to adapt to teaching using ICT claiming they were more comfortable with the old techniques of teaching. Their main concerns were that their school leaver peers were more competent in ICT, and their students were also more likely to know more than themselves. This fear was confirmed by those who had taught using computers before joining the training college as they attested to students having better computer competence than them. In another study on the use of computers in government finance organizations, Elder, Meelissen \& Ruth (1987) found that older workers were more likely to experience techno stress compared to younger workers. Similarly, Harrison and Rainer (1992) examined individual differences on skill in end-user computing and found that age is negatively correlated with skill level. Zeffane and Cheek's (1993) study of computer usage in an Australian telecommunications organization also found that age negatively correlated with computer usage. In the context of the internet, studies show that users tend to be younger adults (Straits and Times, 1996). Age is an important variable for any study on teachers in Kenya. As hiring teachers was irregular over the past two decades; consequently there may be a huge age imbalance in the teaching personnel in public primary schools and this could impact the extent of teacher use of computers and their self-efficacy in integration of ICT.

This article draws from an exploratory study that sought to establish the extent of teacher preparedness to teach using ICT with respect to their training, beliefs and attitudes, and selfefficacy in using ICT in the classroom, and whether these aspects are related to teacher age.

\section{Study Objectives}

1. To establish primary school teacher beliefs and attitudes towards the use of computers in teaching.

2. Determine primary school teacher self-efficacy on teaching using computers.

3. To establish primary school teacher computer competence. 
4. To determine the relationships between teacher age and their beliefs and attitudes towards computers and computer use, self-efficacy, and computer competence.

\section{Methodology}

The study sample was comprised of 236 primary male and female teachers who were teaching standard one to standard three classes in 31 public schools in Kasarani Division, Kiambu County, Kenya. The teachers ranged in age from 21 to 57 years. All the teachers in the sample had a minimum of two years of primary teacher education. Their teaching experience varied from two to 28 years. Lower primary school teachers were chosen for this study as it was common practice in most Kenyan primary schools for a teacher to start with children from class standard one and move with them up to class standard three and then return to class standard one. Going by this practice, it was assumed that the selection group of teachers in lower primary school would be the first cohort of teachers to implement the government ICT lap-top project. The preparation of these teachers was, therefore, critical for successful implementation of ICT in primary school. Teachers were selected with the assistance of school head teachers.

A researcher developed questionnaire consisting of items measuring three dependent variables: beliefs and attitudes towards computers, computer competence, and self-efficacy was used to collect data. Teacher beliefs and attitudes were measured using three subscales that focused on general use of computers, usefulness of computers in teaching, and the use of computers to teach. Computer competence was measured using three subscales relating to basic computer knowledge and skills, ability to teach basic computer knowledge and skills, and ability to teach using computers. Self-efficacy was measured using two subscales. These subscales related to general use of computers, and the use of computers to teach. The teachers completed questionnaires in their schools. Administration of the questionnaires was accomplished by two researchers and two research assistants with support from the school head teachers. This process made it possible to realize a $100 \%$ response rate.

A pilot study was conducted prior to the main study to establish validity and reliability. The pilot study sample consisted of 27 lower primary school teachers from three public schools in Ruiru Zone in Kiambu County, Kenya. These schools were not included in the main study. Test-retest reliability was established for the three questionnaires using Pearson's correlation coefficient test. The reliability coefficients for the three instruments were as shown in Table 1.1.

Expert judgment of ICT trainers and ICT trained teachers established content validity of the instruments. Adjustments were made on items as suggested by the experts. The resulting lists of questions were administered to the 30 teachers in the pilot study and further minor modifications of two items made to ensure item clarity. 
Table 1.1 Pearson's Reliability Coefficients for Test-Retest

\begin{tabular}{|l|l|l|}
\hline \multirow{2}{*}{ Instrument } & Subscale & $\begin{array}{l}\text { Reliability } \\
\text { Coefficient }\end{array}$ \\
\hline \multirow{2}{*}{$\begin{array}{l}\text { Teacher beliefs } \\
\text { and attitudes }\end{array}$} & General use of computers & 0.73 \\
\cline { 2 - 3 } & Usefulness of computers in teaching & 0.75 \\
\cline { 2 - 3 } $\begin{array}{l}\text { Computer } \\
\text { competence }\end{array}$ & Use of computers to teach & 0.81 \\
\cline { 2 - 3 } & Basic computer knowledge and skills & $\mathbf{0 . 7 6}$ \\
\cline { 2 - 3 } Self-efficacy & Ability to teach basic computer knowledge & 0.77 \\
\hline \multirow{2}{*}{\begin{tabular}{l} 
Seneral use of computers and \\
\cline { 2 - 3 }
\end{tabular}} & Use of computers to teach & 0.84 \\
\hline
\end{tabular}

\section{Findings of the Study}

Distribution of teachers by gender, age, and teaching experience data were recorded. The composition of teachers by gender is shown in Table 1.2.

Table 1.2 Distribution of Teachers by Gender

\begin{tabular}{|l|l|l|}
\hline Gender & Number of teachers & Percent (\%) \\
\hline Male & 66 & 33.6 \\
\hline Female & 130 & 66.3 \\
\hline
\end{tabular}

Out of the 236 teachers interviewed, $79(33.6 \%)$ were male and $157(66.3 \%)$ female. There were more female teachers than male teachers. This aligned with Murage (2015) that documented most early childhood teachers in Kenya were as female in other studies. Table 1.3 showed the composition of teachers in this study by age level.

Table 1.3 Composition of Teachers by Age

\begin{tabular}{|l|l|l|}
\hline Age & Number & Percent $(\boldsymbol{\%})$ \\
\hline 21-30 Years & 51 & 21.6 \\
\hline 31-40 Years & 73 & 30.9 \\
\hline 41-50 Years & 60 & 25.4 \\
\hline Above 50 Years & 52 & 22.0 \\
\hline
\end{tabular}

The ages of respondents ranged from 21 to over 50 years, with the majority falling within the 31 40 age group. Although these ages were almost equally distributed, younger teachers in the 2130 age group and relatively older teachers, above 50 years old comprised the minority groups. The comparatively few younger teachers may be because the input of trained teachers to primary schools in Kenya exceeds the current absorption rate of newly trained teachers. This is to reduced hiring rates by the government. Older teachers, on the other hand were fewer due to natural resignations, retirements, and death. Table 1.4 showed the composition of teachers by the number of years of teaching experience.

AJOTE Vol. 5, No. 1 (2016 Edition) 
Table 1.4 Proportions of Teachers by Years of Teaching Experience

\begin{tabular}{|l|l|l|l|}
\hline Years of Teaching & Number of teachers & \multicolumn{2}{|l|}{ Percentage } \\
\cline { 3 - 3 } Experience & & & \\
\hline Below 5 years & 41 & $17.4 \%$ & \\
\hline 5-15 years & 53 & $22.5 \%$ & $39.9 \%$ \\
\hline 16-25 years & 78 & $33.1 \%$ & \\
\hline Above 25 years & 64 & $27.1 \%$ & $60.2 \%$ \\
\hline
\end{tabular}

Majority (33.1\%) of the lower primary teachers' years of teaching experience was between 16 and 25 years. A significant number at $27.1 \%$ had teaching experience totaling more than 25 years. This meant $60.2 \%$ of the teachers had at minimum 16 years of teaching experience. Leaving $39.9 \%$ with less than 15 years of teaching experience. This suggested that there were more older teachers than younger teachers in lower primary school classes.

\section{Teacher Beliefs and Attitudes}

The teacher beliefs and attitudes were measured in relation to the use of computers in general, usefulness of computers in teaching, and using computers to teach. The scores were classified as low (scores between 5 and 15), average (scores between 16 and 25), and high (scores between 26 and 30). The number of teachers in each level of beliefs and attitudes aligned with age levels is shown in Table 1.5.

Table 1.5 Number of Teachers by Level of Belief and Attitude towards Computers Aligned to Age

\begin{tabular}{|c|c|c|c|c|c|}
\hline \multirow[t]{2}{*}{ Attitude Subscale } & \multirow{2}{*}{$\begin{array}{l}\text { Age } \\
\text { (Years) }\end{array}$} & \multicolumn{4}{|c|}{ Level of beliefs and attitudes } \\
\hline & & $\begin{array}{l}\text { Low } \\
(5-15)\end{array}$ & $\begin{array}{l}\text { Average } \\
(16-25)\end{array}$ & $\begin{array}{l}\text { (High } \\
(26-30)\end{array}$ & Total \\
\hline \multirow{4}{*}{$\begin{array}{l}\text { Beliefs and } \\
\text { attitudes towards } \\
\text { use of computers in } \\
\text { general }\end{array}$} & $21-30$ & 8 & 13 & 30 & 51 \\
\hline & $31-40$ & 10 & 24 & 39 & 73 \\
\hline & 41-50 & 21 & 24 & 15 & 60 \\
\hline & Above 50 & 41 & 6 & 5 & 52 \\
\hline \multicolumn{2}{|l|}{ Total } & $80(33.9 \%)$ & $67(28.4 \%)$ & $89(37.7 \%)$ & 236 \\
\hline \multirow{4}{*}{$\begin{array}{l}\text { Beliefs and } \\
\text { attitudes towards } \\
\text { usefulness of } \\
\text { computers in } \\
\text { teaching }\end{array}$} & 21-30 & 10 & 13 & 28 & 51 \\
\hline & $31-40$ & 20 & 20 & 33 & 73 \\
\hline & 41-50 & 32 & 14 & 14 & 60 \\
\hline & Above 50 & 29 & 16 & 7 & 52 \\
\hline \multicolumn{2}{|l|}{ Total } & $91(38.6 \%)$ & $63(26.7 \%)$ & $82(34.7 \%)$ & 236 \\
\hline \multirow{4}{*}{$\begin{array}{l}\text { Beliefs and } \\
\text { attitudes towards } \\
\text { using computers to } \\
\text { teach }\end{array}$} & 21-30 & 9 & 14 & 28 & 51 \\
\hline & $31-40$ & 35 & 21 & 17 & 73 \\
\hline & $41-50$ & 35 & 12 & 13 & 60 \\
\hline & Above 50 & 31 & 15 & 6 & 52 \\
\hline \multicolumn{2}{|l|}{ Total } & $92(39.0 \%)$ & $62(26.3 \%)$ & $82(34.7 \%)$ & 236 \\
\hline
\end{tabular}

AJOTE Vol. 5, No. 1 (2016 Edition) 
Teacher beliefs and attitudes towards use of computers in general at $37.7 \%$ of the teachers demonstrated high or positive beliefs and attitudes. Most of the teachers with high beliefs and attitudes towards use of computers in general were below 40 years of age. In terms of beliefs and attitudes towards usefulness of computers, and towards using computers in teaching, the largest proportion of teachers was at $38.6 \%$ and $39 \%$ respectively that demonstrated low or negative beliefs and attitudes.

When the comparisons are made based on age, majority younger teachers held high or positive attitudes towards use of computers in general. This could be attributed to younger people tended to use and manipulate ICT gadgets, like mobile phones more than the older people. This experience with handheld and other computers likely influenced the younger teachers' beliefs and attitudes in a positive way.

Table 1.6 Pearson's Correlation Coefficient Relationship between Age and Teacher Beliefs and Attitudes

\begin{tabular}{|l|l|l|l|}
\hline \multirow{3}{*}{ Independent } & \multicolumn{2}{|l|}{ Dependent variable } \\
\cline { 2 - 4 } & Beliefs and attitudes towards \\
\cline { 2 - 4 } & General use of & Usefulness of & Using computers to \\
\hline Age & $-.212^{*}$ & $-.231^{*}$ & $-.264^{*}$ \\
\hline
\end{tabular}

As shown in the above Table 1.6, teacher age correlated negatively with all Belief and Attitude dependent variables. That included their beliefs and attitudes toward: i) the general use of computers, ii) usefulness of computers, and iii) use of computers to teach. This meant overall that younger teachers held higher or more positive beliefs and attitudes to computers than older teachers.

\section{Computer Competence}

Table 1.7 shows the number of teachers by age at each level of self-assessed computer competence. The level of perceived computer competence in each of the three subscales included: basic computer knowledge and skills, ability to teach basic computer knowledge, and skills and ability to teach using computers. These are shown aligned with age levels. Most of the teachers that perceived high competence in the three components of computer use were younger, while majority of those who perceived low computer competence tended to be older. The largest proportion of teachers with low perceived competence at $63.1 \%$ reported this low competence in their ability to teach using computers as compared to basic computer knowledge and skills or their ability to teach basic computer knowledge and skills.

Teachers with high perceived computer competence in basic computer knowledge and skills and who felt able to teach such did not necessarily feel capable of teaching using computers. This suggests that teachers felt less competent in teaching using computers than they did in teaching basic computer knowledge and skills.

AJOTE Vol. 5, No. 1 (2016 Edition) 
Table 1.7 Number of Teachers Level of Perceived Computer Competence aligned by Age

\begin{tabular}{|c|c|c|c|c|c|}
\hline \multirow{2}{*}{$\begin{array}{l}\text { Computer } \\
\text { competence } \\
\text { subscale }\end{array}$} & \multirow{2}{*}{$\begin{array}{l}\text { Age } \\
\text { (Years) }\end{array}$} & \multicolumn{4}{|c|}{ Level of perceived computer competence } \\
\hline & & $\begin{array}{l}\text { Low } \\
(5-15)\end{array}$ & $\begin{array}{l}\text { Average } \\
(16-25)\end{array}$ & $\begin{array}{l}\text { (High } \\
(26-30)\end{array}$ & Total \\
\hline \multirow{4}{*}{$\begin{array}{l}\text { Basic computer } \\
\text { knowledge and } \\
\text { skills }\end{array}$} & 21-30 & 7 & 14 & 30 & 51 \\
\hline & 31-40 & 15 & 23 & 35 & 73 \\
\hline & 41-50 & 31 & 16 & 13 & 60 \\
\hline & Above 50 & 32 & 12 & 8 & 52 \\
\hline \multicolumn{2}{|l|}{ Total } & $85(36.0 \%)$ & $65(27.5 \%)$ & $86(36.4 \%)$ & 236 \\
\hline \multirow{4}{*}{$\begin{array}{l}\text { Ability to teach } \\
\text { basic computer } \\
\text { knowledge and } \\
\text { skills }\end{array}$} & 21-30 & 13 & 13 & 25 & 51 \\
\hline & $31-40$ & 14 & 18 & 41 & 73 \\
\hline & 41-50 & 30 & 9 & 21 & 60 \\
\hline & Above 50 & 37 & 8 & 7 & 52 \\
\hline \multicolumn{2}{|l|}{ Total } & $94(39.8 \%)$ & $48(20.3 \%)$ & $94(39.8 \%)$ & 236 \\
\hline \multirow{4}{*}{$\begin{array}{l}\text { Ability to teach } \\
\text { using computers }\end{array}$} & 21-30 & 26 & 15 & 10 & 51 \\
\hline & $31-40$ & 33 & 17 & 23 & 73 \\
\hline & 41-50 & 53 & 4 & 3 & 60 \\
\hline & Above 50 & 37 & 8 & 7 & 52 \\
\hline \multicolumn{2}{|l|}{ Total } & $149(63.1 \%)$ & $44(18.6 \%)$ & $43(18.2 \%)$ & 236 \\
\hline
\end{tabular}

Relationship between Teacher Age and Teacher Perceived Competence

The relationship between a teacher's age and their perceived competency with computers was established using Pearson's product moment correlation east. The correlation coefficients are presented in Table 1.8 .

Table 1.8 Pearson's Correlation Coefficients Relationship between Age and Perceived Computer Competence

\begin{tabular}{|l|l|l|l|}
\hline \multirow{3}{*}{$\begin{array}{l}\text { Independent } \\
\text { Variable }\end{array}$} & \multicolumn{3}{|l|}{ Dependent variable } \\
\cline { 2 - 4 } & \multicolumn{2}{|l|}{ Competence Sub-scale } \\
\cline { 2 - 4 } & $\begin{array}{l}\text { Basic computer } \\
\text { knowledge and skills }\end{array}$ & $\begin{array}{l}\text { Ability to teach } \\
\text { basic computer }\end{array}$ & $\begin{array}{l}\text { Teaching using } \\
\text { computers }\end{array}$ \\
\hline Age & $\mathbf{- . 6 5 4 *}$ & $\mathbf{- . 6 1 3 *}$ & $\mathbf{. 0 7 6}$ \\
\hline
\end{tabular}

Correlation coefficients for the relationships between age and perceived computer competence measures obtained from basic computer knowledge and ability to teach basic computer skills were significant at .05 level of significance. The relationships between age and teachers' perceived competence in basic knowledge and skills and their ability to teach basic computer skills were negative and significant.

AJOTE Vol. 5, No. 1 (2016 Edition) 


\section{Teacher Level of Self-efficacy}

Teachers scores on two self-efficacy subscales were categorized as low (scores between 5 and 15), average (scores between 16 and 25), and high (scores between 26 and 30). As in the case of beliefs and attitudes, teachers below 40 years of age were found to have higher self-efficacy in both general use of computers and using computers to teach. Younger teachers were found to have higher competence levels, and they felt confident in their ability to teach using computers. The subscales used to measure teacher self-efficacy related to computers are demonstrated by the number of teachers by the level of self-efficacy and age level shown in Table 1.9.

Table 1.9 Number of Teachers by Level of Computer Self-efficacy aligned to Age

\begin{tabular}{|c|c|c|c|c|c|}
\hline \multirow{2}{*}{$\begin{array}{l}\text { Self-efficacy } \\
\text { Subscale }\end{array}$} & \multirow{2}{*}{$\begin{array}{l}\text { Age } \\
\text { (Years) }\end{array}$} & \multicolumn{4}{|c|}{ Level of Computer Self-efficacy } \\
\hline & & $\begin{array}{l}\text { Low } \\
(5-15)\end{array}$ & $\begin{array}{c}\text { Average } \\
(16-25)\end{array}$ & $\begin{array}{l}\text { High } \\
(26-30)\end{array}$ & Total \\
\hline \multirow{4}{*}{$\begin{array}{l}\text { Self-efficacy in } \\
\text { general use of } \\
\text { computers }\end{array}$} & 21-30 & 5 & 12 & 34 & 51 \\
\hline & $31-40$ & 18 & 21 & 34 & 73 \\
\hline & 41-50 & 25 & 21 & 14 & 60 \\
\hline & Above 50 & 24 & 19 & 9 & 52 \\
\hline \multicolumn{2}{|l|}{ Total } & $72(30.5 \%)$ & $73(30.9 \%)$ & $91(38.5 \%)$ & 236 \\
\hline \multirow{5}{*}{$\begin{array}{l}\text { Self-efficacy in } \\
\text { using computers } \\
\text { to teach }\end{array}$} & 21-30 & 10 & 10 & 31 & 51 \\
\hline & $31-40$ & 20 & 21 & 32 & 73 \\
\hline & 41-50 & 31 & 17 & 12 & 60 \\
\hline & Above 50 & 31 & 15 & 6 & 52 \\
\hline & & $92(39.0 \%)$ & $63(26.7 \%)$ & $81(34.3 \%)$ & \\
\hline
\end{tabular}

A higher proportion of the teachers with high self-efficacy were the younger teachers. Most of the older teachers had a low or more negative self-efficacy related to computers, thus selfefficacy generally decreased as age of the respondent increased. Younger teachers had more confidence with general use of computers and in using computers to teach since they reportedly comparatively higher use of computers, cell phones, and cameras. Some also reported receiving instruction on computer use in schools and private colleges before joining teacher colleges.

\section{Relationship between Teacher Age and their Self-efficacy in Computers}

The relationship between the teacher age and self-efficacy in the self-efficacy two subscales was established using Pearson's correlation test. Results of this analysis are shown in Table 1.10.

Table 1.10 Pearson Correlation Coefficients Relationship between Age and Self-efficacy

\begin{tabular}{|l|l|l|}
\hline \multirow{3}{*}{ Independent Variable } & \multicolumn{2}{|l|}{ Dependent variable } \\
\cline { 2 - 3 } & Self-efficacy \\
\cline { 2 - 3 } & General use of & Use of computers to \\
\hline Age & $-.219^{*}$ & $-.234^{*}$ \\
\hline
\end{tabular}

AJOTE Vol. 5, No. 1 (2016 Edition) 
Correlation coefficient (-.219) for the relationship between age and self-efficacy were significant for general use of computers. The correlation coefficient (-.234) for the relationship between teacher age and use of computers was significant. This suggested that the teacher self-efficacy in general use of computers and in the use of computers in teaching decreased with increased age.

\section{Discussion}

Younger teachers had higher or more positive beliefs and attitude scores towards usefulness of computers than the older teachers. This could be attributed to the fact that most of the younger teachers graduated from college more recently and were more likely to receive training on computer use as ICT was integrated into the primary teacher education curriculum in 2008. Teachers that graduated after 2008 likely had some training in ICT. This training could have impacted on their attitudes towards ICT and use of computers. A document analysis of the primary teacher education curriculum (Kenya Institute of Education, 2008) showed that acquisition of positive attitudes towards ICT and acquisition of positive attitudes necessary for adapting to a fast-changing technology are some of the notable objectives of the primary teacher education ICT coursework. In addition, younger teachers may have more practice using computers or computer related gadgets more frequently than the older teachers. Young adults reported elsewhere to tend to manipulate and use computers more often than older adults (Zeffane \& Cheek, 1993). This could probably account for the higher or more positive attitudes in the usefulness of computers, and appreciation of their value in teaching. This finding is consistent with findings by Cavas, Cavas, Karaoglan \& Kisla (2009) and Tweed (2013) who found that young Turkish science teachers had significantly higher positive attitudes towards teaching ICT than older teachers.

Teachers felt less competent in teaching using computers than they did in teaching basic computer knowledge and skills. This also suggests that even where a teacher may have basic knowledge and skills, s/he may require extra support or training to feel capable of using computers to teach. A document analysis of the primary teacher education syllabus revealed that the content has focused mainly on computer literacy (knowledge and practical skills on how computers work). There is no explicit content on using computers to teach.

Younger teachers had significantly higher computer competence in their basic computer knowledge and in their ability to teach basic computer skills. However, the correlation coefficient for age and perceived competence to teach using computers was not significant. Furthermore, a large proportion of the youngest and oldest teachers indicated low perceived competence in their ability to teach using computers. Even the young teachers who perceived themselves as competent in teaching basic computer skills did not perceive themselves as capable to teach using computers as much. This suggests that even when teachers perceive themselves as capable of using computers, they may not be able to integrate computers in teaching.

Going by Bordbar (2010) who argues that that teachers' competence in computer use is a good predictor of ICT integration in teaching, one would expect teachers who view themselves as competent in using computers to perceive themselves as competent to teach using computers. This is not fully reflected in the current study findings. This can perhaps be explained by the fact that these teachers may not have specific training in how to integrate computers in their teaching. 
A study by Andoh (2012) reported that teacher training institutions in Ghana emphasized teaching about technology as opposed to how teachers could use technology to teach. Mingaine (2013) reported that secondary school teachers in Kenya did not have sufficient skills on how to integrate ICT in teaching and learning. Thus lower primary school teachers in this study may need specific training on integrating ICT in teaching.

Most of the older teachers had a negative self-efficacy; thus, self-efficacy decreased with age. Younger teachers had more confidence with general use of computers and in using computers to teach since they reported more use of computers, cell phones, and cameras. Some also reported receiving instruction on using computers in schools and private colleges before joining teacher colleges.

The younger respondents expressed higher confidence in their ability to teach using computers than the older respondents. This finding was consistent with Gill \& Dalgarno's (2008) that most of the mature teachers expressed reluctance to adapt to teaching using ICT claiming they were comfortable with the old techniques. This was paired with younger adults being more conversant with computers, so were more likely to expect less frustration when they work with computers.

\section{Conclusion}

The findings of this study imply that provision of computers and infrastructure in schools will not necessarily guarantee that teachers will integrate ICT in schools. There is need to pay attention to primary school teachers' beliefs and attitudes and particularly those that older teachers have towards the use of computers. Attitudes are a strong influence of teachers' behavior with ICT. Older teachers in this study overall held negative beliefs and attitudes in the three components of computer attitudes. It is important for the Ministry of Education to address teachers' attitudes and beliefs towards computers and their use in teaching.

This calls for the need to provide ICT training to long serving teachers, especially those that went through training before ICT was integrated into the teacher education curriculum. Even where teachers perceive themselves as knowledgeable in operating computers, they may not be able to integrate computers in teaching unless they receive specific training on how to teach using computers. Thus, such teachers may need specific training on integrating ICT in teaching. The Ministry of Education may, therefore, need to provide professional development coursework on ICT integration in teaching for such teachers. Such training could take an in-service mode structured in such a way that it may be conducted during holiday sessions to make it possible for practicing teachers to be available for training.

To enhance teacher preparation, the current primary teacher education curriculum should be revised to include content on ICT pedagogy. This will help to ensure that trainers focus on developing teachers' knowledge and skills for teaching using computers in addition to teaching computer literacy.

The current study only focused on computers. There are other ICT tools that could be used in the integration of ICT in teaching and learning. This study should be replicated with primary teacher educators as their role is critical in determining the competence of the effectiveness of the teacher preparation process. 


\section{REFERENCES}

Aktaruzzaman, M. Shamim, R.H., \& Clement C.K. (2011). Trends and issues to integrate ICT in teaching learning for the future world of education. International Journal of Engineering and Technology, 11(3), 114-119.

Andoh, B. (2012). An exploration of teachers' skills, perceptions and practices of ICT in teaching and learning in Ghanaian second-cycle schools. Contemporary Education Technology, 3(1), 36-49.

. (2012). Factors influencing teachers' adoption and integration of information and communication technology into teaching: a review of the literature. International Journal of Education and Development Using Information and Technology, 8(1), 36-155.

Ayere F. Odera Y \& Agak, J. (2010). E-learning in secondary schools in Kenya: A case of the Nepad E-Schools. Educational Research and Reviews, 5(5), 218-223.

Benson, S. (2004). Computer anxiety: Impediment to technology integration? Retrieved from http://pt3.nmsu.edu/research/Benson.html.

Bikos, K. and Tzifopoulos, M. (2011). Teachers and ICT: Facilitators and animators in the use of digital implementation and application in school classes. Proceedings, $2^{\text {nd }}$ Panhellenic Conference: Integration and use of ICT in Educational Process, 235-245.

Boardbar, F. (2010). English teachers' attitudes toward computer-assisted language learning. International Journal of Language Studies, 4(3), 27-54.

Brush, T., Glazew, K.D. and Hew, F.K.F. (2008). Development of an instrument to measure preservice teachers' technology skills, technology beliefs, and technology barriers. Computers in the Schools, 25,112-125.

Castrol Sanchez, J.J. and Aleman, E. C. (2011). Teachers' opinion survey on the use of ICT tools to support attendance-based teaching. Journal Computers and Education, 56, 911-915.

Cavas, B., Cavas B., Karaohlan, B. \& Kisla, T. (2009). A study of science teachers toward information and communication technologies in education. The Turkish Online Journal of Educational Technology-TOJET, 8 (2), 20-32.

Compeau, D.R., \& Higgins, C.A. (1995). Computer self-efficacy: Development of a measure and initial test. MIS Quarterly, 23(2), 145-158.

Drent, M. \& Meelissen, M. (2008). Which factors obstruct or stimulate teacher educators to use ICT innovatively? Computers \& Education 51(1), 187-199.

Elder, V.B., Gardner, E.P. and Ruth, S.R. (1987). Gender and age in technostress: Effects on 
white-collar Productivity. Government Finance Review, 3(6), 17-21.

Eugene, J. (2006). How teachers integrate technology and their beliefs about learning: Is there a connection? Journal of Technology and Teacher Education, 51(1), 187-199.

Gill, L. \& Dalgarno, B. (2008). Influences on pre-service teachers' preparedness to use ICTs in the classroom. In Hello! Where are you in the landscape of educational technology? Proceedings ascilite Melbourne. Retrieved from http://www.ascilite.org.au/conferences/melbourne08/procs/gill.pdf

Harrison, A.W. and Rainer, R.K. Jr. (1992). The influence of individual 1 differences on skill 1 in end-user computing. Journal of Management Information Systems, 9(1), 93-111.

Hew, K. F., \& Brush, T. (2007). Integrating technology into K-12 teaching and learning: Current knowledge gaps and recommendations for future research. Educational Technology Research and Development, 55, 223-253.

Huang, H.M., \& Liaw, S.S.T. (2005). Exploring users' attitudes and intentions toward the Web as a survey tool. Computers in Human Behavior, 21(5), 729-743.

Keengwe, J., \& Ochwari, G. (2008). Computer learning: barriers and promise. Journal of Science Education and Technology, 17, 560 -565.

Kenya Government. (2007) Vision 2030. Nairobi: Government of the Republic of Kenya.

Kenya Institute of Education (KIE), (2008). Primary teacher training syllabus. Nairobi: KIE.

Knezek, G. \& Christensen, R. (2000). Impact of new information technology on teachers and students. Education and Information Technologies, 7(4), 369-376.

Koliadis, E. (1997). Learning Theories and Educational Act. Vol B \& C. Athens, Greece: Ellinika Grammata.

Mingaine, L. (2013) Skill challenges in adoption and use of ICT in public secondary schools in Kenya. International Journal of Humanities and Social Sciences, 3(13), 61-72.

Murage, M. (2015). Influences of male enrollment in early childhood development training programmes in Kenyatta University. Kenyatta University. Unpublished Masters Thesis.

Muriithi, P. (2005). A Framework for Integrating ICT in the Teaching and Learning Process in Secondary Schools in Kenya. Unpublished MSC Thesis: University of Nairobi, Kenya.

Ng'eno, J., Githua, B., \& Changeiywo, J. (2013). Teachers' perceptions of their preparedness to integrate information communication and technology in secondary school mathematics instruction in Rift Valley Region, Kenya. Journal of Education and Practice, 4(12),

AJOTE Vol. 5, No. 1 (2016 Edition) 
2013.

Ogutu, J. O. (2008). The impact of ICT integration in the six Nepad e-schools in Kenya. Retrieved from http:/profiles.uonbi.ac.ke/jogutu/publications.

Shan Fu, J. (2013). ICT in Education: A Critical Literature Review and its Implications. International Journal of Education and Development Using Information and Communication Technology (IJEDICT), 9(1), 112-125.

Simonson, M. (2008). Technology use of Hispanic bilingual Teachers: A function of their beliefs, attitudes and perceptions on peer technology use in the classroom, Journal of Instructional Technology, 31(3), 257-266.

Straits Times. (November 12, 1996). Finding out who surfs the Internet is their business, Singapore.

Teo T. (2009). Examining the relationship between student teachers' self-efficacy, beliefs and their intended uses of technology for teaching: A structural equation modeling approach. The Turkish Online Journal of Educational Technology (TOJET), 8(4), 7-15.

Tweed, S. R. (2013). Technology Implementation: Teacher Age, Experience, Self-Efficacy, and Professional Development as Related to Classroom Technology Integration. Electronic Theses and Dissertations. Retrieved from Paper 1109. http://dc.etsu.edu/etd/1109

Woodrow, J. E. (1992). The influence of programming training on the computer literacy and attitudes of pre-service teachers. Journal of Research on Computing in Education, 25(2), 200-219.

Zeffane, R. and Cheek, B. (1993). Profiles and correlates of computer usage: A study of the Australian telecommunications industry. Computers in Industry, 22, 53-69. 